\title{
PLANT HEALTH AND HOW IT AFFECTS PRIVATE GARDENS: EXPERIENCE FROM A BOTANIC GARDEN PATHOLOGIST
}

\author{
Stephan Helfer ${ }^{1}$
}

Like many other botanic gardens the Royal Botanic Garden Edinburgh provides advice about plant pests and diseases to amateur gardeners. This paper summarises the main problem plant categories (such as trees and vegetables), plant problems (such as pests or fungal infection) and other observations, such as number of enquiries by month noted by pathology staff at the Garden over the last twenty years.

As well as experiencing great satisfaction and joy with their plants, most amateur gardeners will surely have experienced the occasional disappointment with their appearance. Most professional gardeners probably have done so too. What I mean is not that we have chosen the wrong plants for the spot or have been negligent in looking after them, but that there was a pest or disease problem with the plants or that the environment was unsuitable.

After the choice of plants from an aesthetic and horticultural point of view, plant health must be the next most important issue for the home gardener. Whilst this may not be immediately obvious when a new plant is introduced into the garden it may soon become apparent, should this new arrival not fare as well as hoped for.

Over the past twenty years or so I have been involved with giving members of the public advice on plant health problems. Preliminary results have been published in specialist literature (Helfer 2000 and 2003). Whilst we do not advertise this service (we do not wish to be inundated with requests) and our sample is therefore very limited, we have been able to record our plant health experiences from a small section of Scottish gardens over the past fifteen years and enter them into a database. Data extracted from our records have been used to assess the three following questions concerning plant health in (mainly urban) private gardens:

- Which types of plants are most commonly affected by problems, for which expert advice is sought?

- What are the most common causes for ill health in these plants?

- What is our most effective advice on the treatment of these plants?

In the case of mixed or multiple problems I have chosen the main issue. For example, if the enquiry was about a fruit tree the record was made depending on which problem, fruit production or tree health, was causing the most concern. Where more than one problem occurred on the same specimen, for example aphids and mildew, both were entered into the database.

The collated data show an interesting monthly distribution (Figure 1). Although there are some problems in any month, the main plant health issues come to the surface in the summer (with a 'holiday dip' in July) and autumn.

\footnotetext{
' Stephan Helfer is a Plant Pathologist at RBGE. Address:20a Inverleith Row, Edinburgh EH3 5LR. Email:s.helfer@rbge.org.uk
} 


\section{RESULTS AND DISCUSSION}

enquiries by month

1991-2004

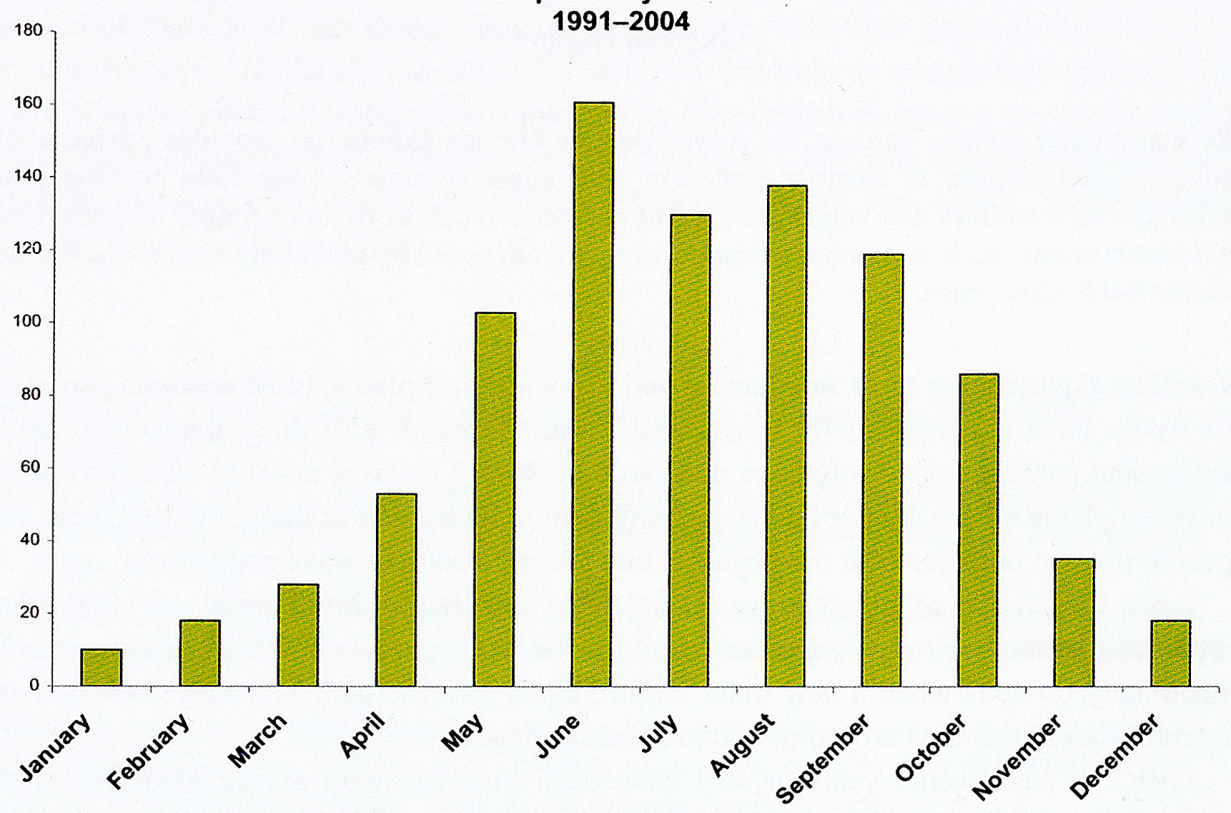

Figure 1. Spread of plant health enquiries during the last 14 years.

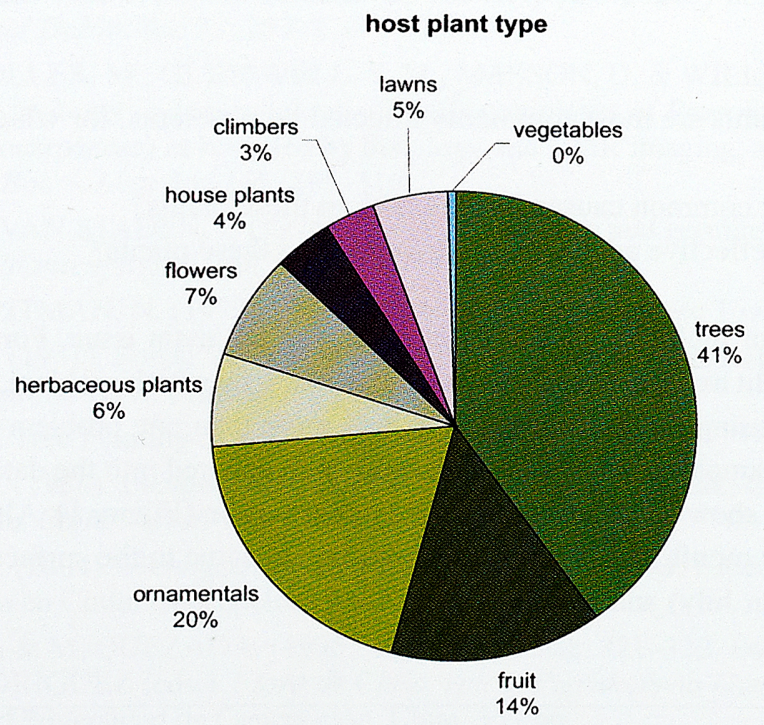

Figure 2. Plant problem enquiries by host plant type. 


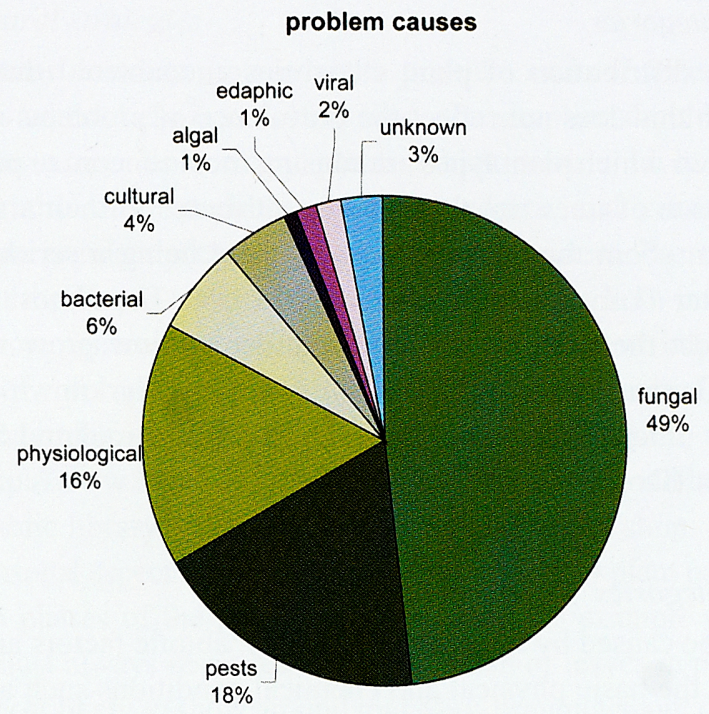

Figure 3. Causes of problems in private gardens

recommended controls

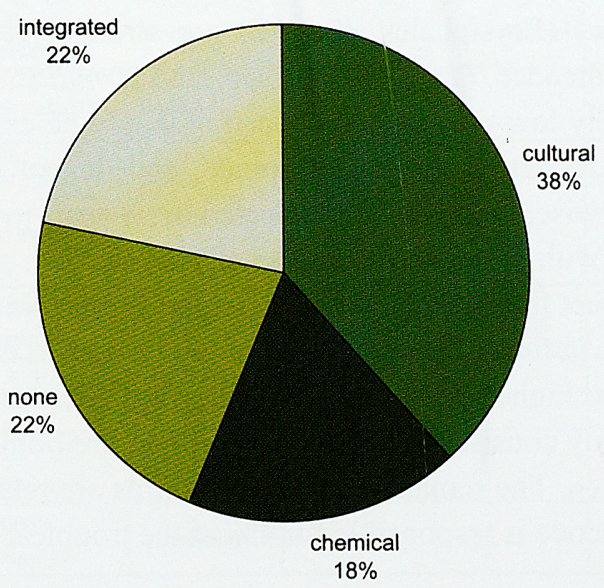

Figure 4. Recommended control methods. 


\section{Problem plant categories}

Figure 2 shows the distribution of plant categories encountered during the past 15 years. In my opinion this does not reflect the prevalence of problems inherent to these plants. It merely shows which plant types are causing most concern to private gardeners. The prominent position of trees can therefore be attributed to their size and longevity and people's concern about the consequences of there being a serious problem with them (see also chapter 11 in Ingram \& Robertson, 1999). The almost total absence of vegetables may reflect the fact that not many gardeners now grow vegetables. Also the Royal Botanic Garden, Edinburgh (RBGE) is not exactly known for its expertise in vegetable matters. Interestingly, data from the Royal Horticultural Society are very similar in this respect (Dr Chris Prior, pers comm).

\section{Plant problem categories}

Plant ill health may be caused by two main categories: abiotic factors and biotic agents. The former includes the basic physical and chemical conditions such as lack or excess of light, frost, drought or water logging. Additional abiotic factors are chemical toxicity and nutrient deficiencies or imbalances. The latter includes problems caused by disease and pest organisms such as aphids, mildews, bacteria and viruses. Added to these can be problems related to unsuitable horticultural care. Examples of this could include the incorrect application of pesticides or inappropriate pruning or mulching. I hesitate slightly to put these problems into the second category because the cause originates with humans. Often the apparent ill health of plants is due to factors in both categories, and a plant growing vigorously in the most suitable environment, is far less likely to contract biotic diseases, let alone succumb to them. Conversely, what starts as a minor environmental problem may end up with a plant killed by pathogens.

Our data shows that plant problems most often encountered in private gardens are caused by fungi (Figure 3). This is not altogether surprising as $70 \%$ of plant diseases world wide are caused by these organisms (Kendrick, 2003). The rusts (Uredinales, Plate 1) and mildews (Erysiphales, Plate 2) are strongly represented here, as are lawn fungi and the dreaded Phytophthora spp. and Armillaria spp. (Honey Fungus, Plate 3). The relatively low count for pests can probably be explained by the fact that most gardeners can recognise slugs and aphids, and do not need to ask for expert identifications. Otherwise, I would have expected these pests to top the problem causes from the experience with slugs, snails and sawfly in my own garden!. There is also a possible bias in the fact that RBGE has mycologists on the staff, and that people may know of our expertise in fungi. Physiological problems such as drought, frost or nutrient imbalance are the next highest in the problem category. These are followed by bacterial problems which mainly consist of bacterial canker and fire blight, which is also caused by a bacterial pathogen. The remaining problem causes are relatively rare (each under $5 \%$ ). Cultural malpractice is responsible for $4 \%$ of the troubles. 


\section{Advice on control strategies}

What can a gardener do when a plant health problem strikes? (See Box 1) There are a number of places where help is on offer: First, the supplier should be willing to offer advice and, if necessary replace any plants which were sold in an unfit condition. Television and radio offer popular gardening advice and some of the gardening magazines provide regular 'problem pages' for their readers. For the more committed garden enthusiast the Royal Horticultural Society provides both problem identification and advice and more general horticultural guidance to members (http://www.rhs.org.uk). Further sources of information include among others the Henry Doubleday Research Association (membership encouraged, see http://www.hdra.org.uk) and institutions such as the RBGE (http://www.rbge.org.uk). There are also many good books available; have a look in your public library, garden centre or any good book shop.

There is a seasonal aspect to plant pathology, in that many plant problems occur during particular growth phases of the plant. Peach leaf curl for example (caused by Taphrina deformans) is almost always restricted to the first flush of leaves in peaches, almonds and nectarines. It is most likely to show around mid May, bringing about distorted, discoloured (red to purple) leaves, which drop prematurely. Normally this is followed by a new flush of leaves, which are entirely healthy. Similarly, fire blight (caused by Erwinia amylovora) normally attacks plants only after a warm spell shortly after the trees such as apple, pear and cotoneaster have flowered (April - May). The fruiting bodies of many fleshy fungi (such as Armillaria spp. or Marasmius spp.) only show towards the end of summer. The fungi are in fact present and causing damage all year round, often unseen as microscopic threads called mycelium. Knowledge of the biology of the pathogens enables us to predict their occurrence, and hopefully to prevent, contain or control them.

\begin{tabular}{|l|l|l|l|l|l|l|l|}
\hline \multicolumn{1}{|c|}{ Name } & \multicolumn{1}{|c|}{ Service } & \multicolumn{1}{|c|}{$\begin{array}{c}\text { Annual } \\
\text { Usage }\end{array}$} & Open To & Charge & Membership & Data Base & Notes \\
\hline $\begin{array}{l}\text { BBC radio \& } \\
\text { television }\end{array}$ & $\begin{array}{l}\text { problem } \\
\text { diagnostics }\end{array}$ & $\begin{array}{l}\sim 1000 \\
\text { enquiries }\end{array}$ & public & none & none & $\begin{array}{l}\text { broadcasting } \\
\text { bias }\end{array}$ \\
\hline $\begin{array}{l}\text { CABI } \\
\text { bioscience }\end{array}$ & $\begin{array}{l}\text { fungal } \\
\text { diagnostics }\end{array}$ & $\begin{array}{l}300 \\
\text { specimens }\end{array}$ & limited & $£ 120.00$ & governmental & not available & $\begin{array}{l}\text { really only } \\
\text { commercial }\end{array}$ \\
\hline CSL & $\begin{array}{l}\text { problem } \\
\text { diagnostics }\end{array}$ & not stated & limited & $£ 52.50$ & not available & public body \\
\hline $\begin{array}{l}\text { Forest } \\
\text { Research }\end{array}$ & $\begin{array}{l}\text { tree problem } \\
\text { diagnostics }\end{array}$ & not stated & public & $£ 20-60$ & not available & public body \\
\hline $\begin{array}{l}\text { Garden } \\
\text { Centres }\end{array}$ & $\begin{array}{l}\text { problem } \\
\text { diagnostics }\end{array}$ & $\begin{array}{l}1000 s \\
\text { enquiries }\end{array}$ & public & $\begin{array}{l}\text { normally } \\
\text { none }\end{array}$ & none & $\begin{array}{l}\text { commercial } \\
\text { interest }\end{array}$ \\
\hline HDRA & $\begin{array}{l}\text { problem } \\
\text { diagnostics }\end{array}$ & $\begin{array}{l}4000 \\
\text { enquiries }\end{array}$ & $\begin{array}{l}\text { membership/ } \\
\text { public }\end{array}$ & none & encouraged & not available & $\begin{array}{l}\text { organic } \\
\text { association }\end{array}$ \\
\hline HRI & $\begin{array}{l}\text { problem } \\
\text { diagnostics }\end{array}$ & not stated & public & not stated & & not available & public body \\
\hline $\begin{array}{l}\text { RBG } \\
\text { Edinburgh }\end{array}$ & $\begin{array}{l}\text { problem } \\
\text { diagnostics }\end{array}$ & $\begin{array}{l}120 \\
\text { specimens }\end{array}$ & public & none & & available & public body \\
\hline RHS & $\begin{array}{l}\text { problem } \\
\text { diagnostics }\end{array}$ & $\begin{array}{l}2000 \\
\text { enquiries }\end{array}$ & membership & none & required & available & $\begin{array}{l}\text { charitable } \\
\text { society }\end{array}$ \\
\hline
\end{tabular}

Box 1. Sources of plant health advice in the United Kingdom. 


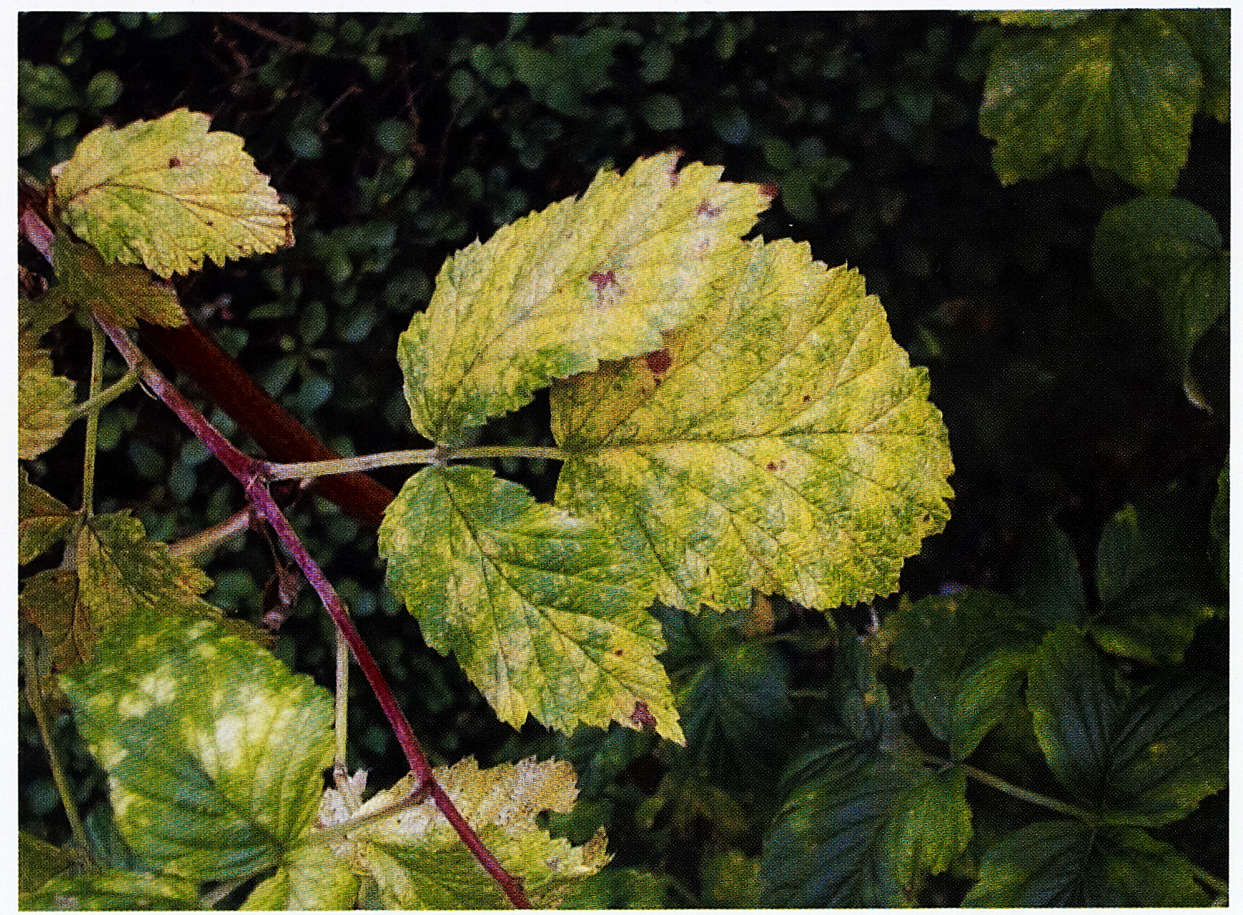

Plate 1. Raspberry rust, Phragmidium rubi-idaei

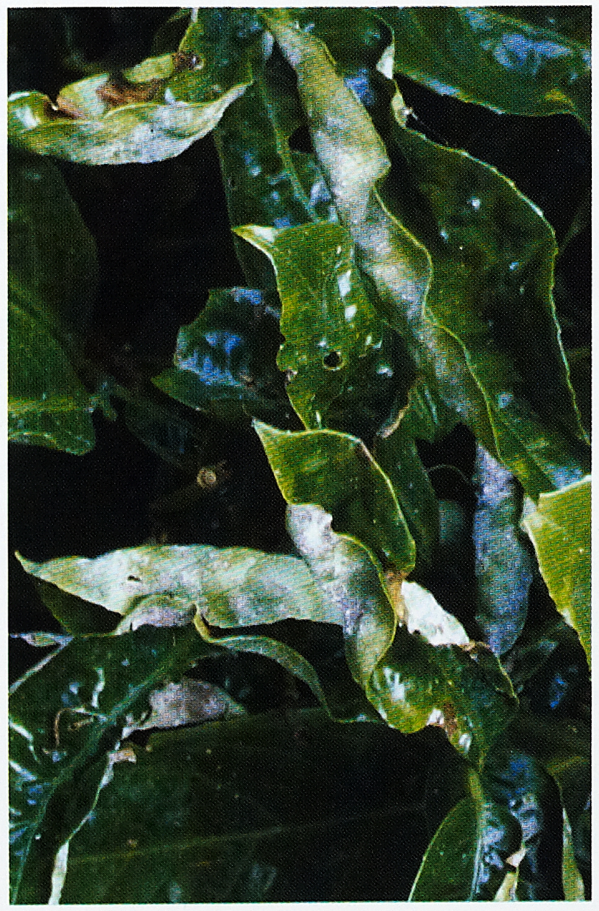

Plate 2. Powdery mildew on Cherry laurel

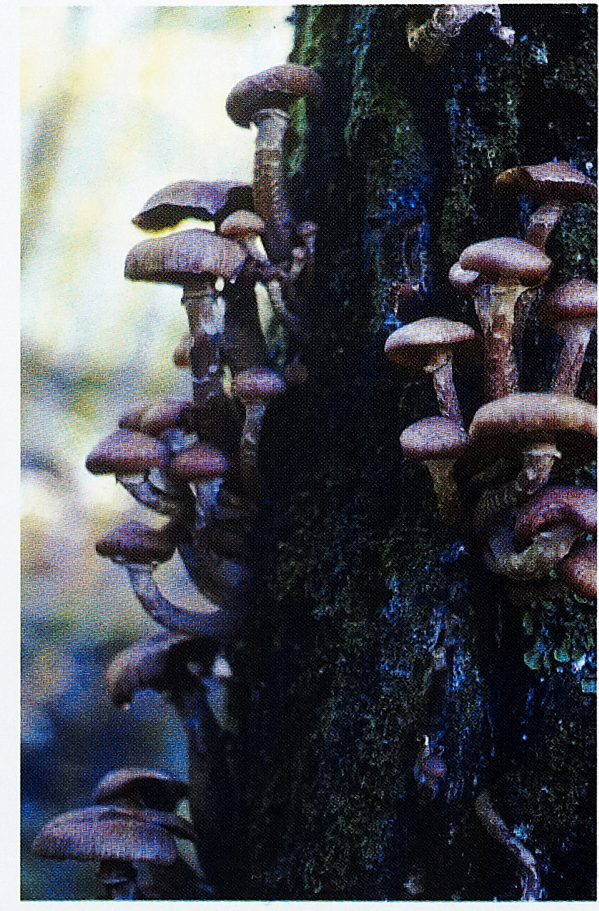

Plate 3. Honey fungus, Armillaria mellea 
Our advice is normally balanced between the attempt to stay 'chemical free' and the availability and effectiveness of alternative control methods. Some enquirers specify what methods would be acceptable to them, others are anxious for any advice available. Figure 4 shows a distribution of advice given by us concerning control methods. In almost $25 \%$ of cases the advice is to simply wait and do nothing. $38 \%$ required cultural control methods and in $18 \%$ chemical control was considered most appropriate. It is important to follow official recommendations on the use of pesticides, and I recommend that readers in Britain consult the most up to date publications from the Pesticide Safety Directorate. The remaining $22 \%$ of problems called for an integrated method, requiring some chemicals combined with cultural control methods. Many plant problems can be controlled or substantially reduced by horticultural methods, such as judicial pruning, hygiene, or the use of mulches and fertilisers. Sometimes more radical methods are called for such as moving the plant to a more suitable environment. A plant which presents a risk to other plants, people or property must be destroyed by burning. As with many troubles, much harm can be avoided if the problem is diagnosed in its initial stages. All this requires a certain amount of knowledge, and most importantly, vigilance.

\section{CONCLUSIONS}

Plant health issues are important for all gardens and all gardeners. There is currently a lack of information on basic data concerning plant health problems in private gardens, despite their obvious appreciation in urban landscapes and their value for the quality of life in urban and suburban areas. Trees cause greatest concern in plant health enquiries, and fungi rank highest as organisms causing ill health in plants. Further research, especially involving random surveys would be helpful in scientifically assessing the full impact of plant health issues on private gardens.

\section{REFERENCES}

HELFER, S. (2000). Plant Health in private urban gardens in Scotland. Backhaus GF, Balder $\mathrm{H}$ and Idczak E Plant Health in Urban Horticulture. Mitteilungen der Biologischen Bundesanstalt für Land und Forstwirtschaft Nr 370:287.

HELFER, S. (2003). Plant Pathology in private gardens 8th International Congress of Plant Pathology II, offered papers 136.

INGRAM, D. and ROBERTSON, N. (1999). Plant Disease-A Natural History. Harper Collins. KENDRICK, B. (2003). The Fifth Kingdom. Cd-rom Mycologue Publications. 
